\title{
DUT Guide om løbende bedømmelse
}

Ole Eggers Bjælde ${ }^{1}$, Centre for Educational Development, Aarhus Universitet og Institutt for Pedagogikk, Universitet i Bergen

Annika Büchert Lindberg, Centre for Educational Development, Aarhus Universitet

\begin{abstract}
Løbende bedømmelse er en relativt ny eksamensform i Danmark, som giver mulighed for at supplere en afsluttende eksamen med bedømmelsesaktiviteter i løbet af undervisningsperioden, som tæller med i den studerendes samlede karakter. Løbende bedømmelse kan derfor blive en måde, hvorpå eksamen knyttes bedre til undervisningen og giver de studerende mere retvisende eksamenskarakterer. Med fokus på bedre uddannelse og undervisning på de videregående uddannelser vil det formentlig blive en mere udbredt eksamensform med tiden. I guiden her præsenteres praksisnære råd til undervisere og undervisningsudviklere om løbende bedømmelse baseret på forskning, danske og internationale erfaringer samt den hidtidige implementering af eksamensformen på danske videregående uddannelser.
\end{abstract}

\section{Praktiske pointer}

1. Gør det klart, hvad du vil udprøve med løbende bedømmelse

2. Gennemtænk dit design af løbende bedømmelse

3. Lad være med at stresse de studerende

4. Gør bedømmelse mere autentisk

5. Giv mere anvendelsesorienteret feedback

6. Brug de studerende som en ressource

7. Vær opmærksom på, hvad du må og ikke må juridisk

8. Anvend data til at forbedre din løbende bedømmelse iterativt

\section{Baggrund}

Løbende bedømmelse blev tilladt inden for de videregående uddannelser i Danmark i 2016 med en reform af eksamensbekendtgørelsen. Den nye bekendtgørelse tillader "at bedømmelsen af skriftlige opgavebesvarelser og mundtlige fremlæggelser m.v. i løbet af undervisningsforløbet indgår som en del af karakterfastsættelsen sammen med den afsluttende prøve i et fag eller fagelement" (Eksamensbekendtgørelsen, 2020). På den måde har undervisere fået mere frihed til at vælge bedømmelsesform, så længe det fremgår "af eventuelle regler, hvorledes bedømmelsen af de skriftlige opgavebesvarelser og mundtlige fremlæggelser m.v. indgår i den samlede bedømmelse af faget eller fagelementet" (Eksamensbekendtgørelsen, 2020).

\footnotetext{
${ }^{1}$ Kontakt: oeb@au.dk
} 
At brugen af løbende bedømmelse har ministeriel opbakning blev videre underbygget af Udvalg om bedre universitetsuddannelser, som i rapporten "Universitetsuddannelser til fremtiden" angiver "At der skabes bedre mulighed for løbende bedømmelse af studerende med henblik på et øget læringsudbytte" (Universitetsuddannelser til fremtiden, 2018) som deres anbefaling nummer 23 ift. at styrke de danske universitetsuddannelser.

På trods af den ministerielle opbakning er udbredelsen af løbende bedømmelse på de danske universiteter ifølge vores samtaler med undervisningsudviklere og en ikke-systematisk analyse af kursusbeskrivelser på Aarhus Universitet foregået med langsomme skridt. Derfor vil vi med denne DUT-guide om løbende bedømmelse søge at udbrede kendskabet til forskellige formater for løbende bedømmelse, præsentere nogle af de gode erfaringer med løbende bedømmelse samt berette om flere af de mulige faldgruber og udfordringer med løbende bedømmelse for både dig som underviser og for dig, som udvikler undervisning.

I denne DUT-guide anvendes begreber som udprøvning, vurdering, bedømmelse og eksamen bevidst som synonymer på, at de studerendes opnåelse af læringsmål udprøves/vurderes/bedømmes, hvorimod evalueringsbegrebet kun anvendes til at beskrive de studerendes evaluering af undervisningen (Bjælde et al., 2017; Raaheim 2016).

\section{Løbende bedømmelse}

Et bud på en egentlig definition på løbende bedømmelse er "bedømmelser, der foregår som pointgivende aktiviteter fordelt i løbet af et undervisningsforløb" (Oversat fra Bjælde et al., 2017). Bemærk, at vi bevidst benytter ordet pointgivende frem for karaktergivende, da den danske implementering af formatet er, at den løbende bedømmelse indgår $\mathrm{i}$ en helhedsvurdering sammen med en eventuel afsluttende eksamen. Derved undgås en central, men udfordrende rettighed i den danske eksamensbekendtgørelse; at studerende har tre forsøg til alle eksamener eller deleksamener (Eksamensbekendtgørelsen, 2020). Så snart der gives karakterer til bedømmelsesaktiviteter, bliver de til deleksamener, hvilket kan være uhensigtsmæssigt rent administrativt. Løbende bedømmelse skal således ikke ses som individuelle deleksamener, men som en helhed i fællesskab med en eventuel afsluttende eksamen. Bemærk, at vi her må tage forbehold for en konkret juridisk vurdering i enkelte tilfælde.

Indførelsen af løbende bedømmelse på videregående uddannelser er ikke ny internationalt, idet universitetsstuderende i fx USA, England og Australien samt store dele af universiteterne i de engelsktalende lande har benyttet sig af løbende bedømmelse i årtier.

\section{Hvorfor løbende bedømmelse?}

Mange undervisere er i undervisningen blevet stillet følgende spørgsmål af deres studerende "Er det her relevant til eksamen?". Det er derfor ikke overraskende, at eksamen længe har været beskrevet som den vigtigste drivkraft for de studerendes læring (Ramsden, 2003; Winstone \& Carless, 2020). Ramsden (2003) har understreget dette med citatet "assessment always defines the actual curriculum". Eksamen og udprøvning bør derfor ikke alene ses som en aktivitet, der afslutter et kursus (assessment of learning), men som en integreret del af kursusdesignet (assessment for learning). Gibbs (2006) anbefaler derfor, at bedømmelse, som har til formål at understøtte de studerendes læring, bør være jævnt fordelt i undervisningsperioden, og at bedømmelserne skal engagere de studerende i produktive læringsaktiviteter. Det har samtidig den fordel, at det gør de studerende mere bevidst om egne evner, hvilket både Hattie (2015) samt Schneider \& Preckel (2017) fremhæver 
som en af de vigtigste faktorer for at opnå et højt læringsudbytte. Løbende bedømmelsesaktiviteter giver således mulighed for at sætte fokus på læringsprocessen imod et slutprodukt ved at gøre læringsprocessen til genstand for bedømte aktiviteter (de la Harpe et al., 2009). Det skift i fokus væk fra slutproduktet kan være med til at vise studerende, at selve læringsprocessen også har værdi og at hjælpe studerende til at få en god læringsproces ved at have tydelige kriterier for proces foruden produkt, hvor man fx kan belønne studerende for at tage chancer eller at have et stærkt argument for en ide.

Begrundelsen for, at udvalgte læringsaktiviteter skal pointgives - dvs. være summative og ikke blot indeholde formativ feedback - er, at de studerende med større sandsynlighed investerer tid og kræfter i aktiviteter, der direkte bidrager til en forbedret karakter, og derved producerer arbejde med højere kvalitet (Carless, 2015; Winstone \& Carless, 2020). Samtidig vil de studerende derved fordele deres arbejdsindsats over en længere periode modsat (for nogle) blot at arbejde intenst i perioden op imod den afsluttende eksamen, hvilket antageligvis vil bidrage til at fastholde viden i længere tid (Trotter, 2006; Gibbs and Lucas, 1997; Bjælde et al., 2017).

I Danmark har traditionen været, at den studerende bedømmes på en enkelt præstation til den afsluttende eksamen, som derfor kan betegnes som en "højrisiko"-eksamen. Ved at omlægge til løbende bedømmelse deltager de studerende i flere ofte forskelligartede "lavrisiko"-udprøvninger og har derfor en pejling på, hvorvidt de er på rette vej undervejs $i$ et kursus. Disse summative udprøvninger med lav risiko suppleret med formativ feedback har desuden vist sig at kunne styrke de studerendes motivation og selvværd (Nicol \& Macfarlane-Dick, 2006), og generelt klarer de studerende sig godt i løbende bedømmelse (Heywood, 2000; Bjælde et al., 2017)

Andersen og Tofteskov (2016) beskriver i bogen "Eksamen og eksamensformer", som udkom inden den reviderede eksamensbekendtgørelse, at eksamen skal tilrettelægges på basis af gyldighed, reliabilitet og økonomi. Gyldigheden af løbende bedømmelse er hovedfokus for hele denne DUT-guide og udfoldes specifikt under pointe 1. Men også reliabiliteten af eksamen, som beskriver, hvor præcis og ensartet en bedømmelse er, kan styrkes gennem løbende bedømmelse. Dette kan blandt andet gøres ved, at både underviseren og de studerende er bekendte med de bedømmelseskriterier, som anvendes. Andersen og Tofteskovs (2016) pointe om, at eksamener er dyre at afholde, nødvendiggør, at den løbende bedømmelse netop planlægges, så den skaber så meget værdi som muligt ved fx at understøtte flere formål som at give de studerende feedback eller involvere dem i autentiske udprøvninger. Man skal endvidere holde sig for øje, at en eventuel afsluttende eksamen med fordel kan reduceres i omfang, når den kombineres med løbende bedømmelse.

\section{Pointe 1: Gør det klart, hvad du vil udprøve med løbende bedømmelse}

I kurser med constructive alignment (Biggs \& Tang, 2011) understøttes kursets læringsmål af relevante læringsaktiviteter, og disse læringsaktiviteter gør den studerende i stand til at opfylde læringsmålene tilfredsstillende ved eksamen. I kurser med løbende bedømmelse vil nogle af disse læringsaktiviteter blive bedømt undervejs i kurset, hvorved nogle læringsmål kan opfyldes helt eller delvist. Der kan dog også være andre formål med løbende bedømmelse:

- Løbende bedømmelsesaktiviteter kan udvælges, fordi de understøtter faglige læringsmål i et kursus, som danner basis for kursets øvrige læringsmål. Det kunne fx være anvendelse af faglige begreber, som de studerende skal beherske, inden de kan læse videnskabelige artikler eller deltage i faglige diskussioner på højere taksonomiske niveauer. Læringsaktiviteter kunne være små tests eller essays, hvor studerende øver deres forståelse af faglige begreber og deres anvendelse. 
- Løbende bedømmelsesaktiviteter kan give studerende mulighed for at øve sig gennem flere iterationer med feedback. Eksempler kunne være aktiviteter, hvor de studerende træner deres skrive- og regnefærdigheder og efterfølgende får både formativ og summativ feedback. For at det ikke opleves uretfærdigt at blive udprøvet i færdigheder/viden, man er i gang med at tilegne sig, er det vigtigt, at de studerende får feedback og mulighed for at forbedre sig. Ligeledes kan vægtningen sættes lavt, og man kan overveje blot at belønne deltagelse i læringsaktiviteterne.

- Løbende bedømmelsesaktiviteter kan give mulighed for at udprøve læringsmål, som kan være udfordrende at udprøve ved en traditionel skriftlig eller mundtlig eksamen. Dette kunne eksempelvis være udprøvning af læringsmål med fokus på praktiske færdigheder i laboratoriet eller klinikken (Hunt et al., 2012; Newble et al., 1994; ten Cate et al., 2021), samskabelse af kreative løsningsforslag samt samarbejde med og formidling til eksterne aktører (Bjælde \& Najbjerg, 2017).

\section{Pointe 2: Gennemtænk dit design af løbende bedømmelse}

På trods af at udbredelsen af løbende bedømmelse har været begrænset på de danske universiteter, har udformningen af løbende bedømmelsesaktiviteter været mangfoldig. Vi vil i det følgende samle den mangfoldighed i to eksamensformer.

I begge eksamensformer er den løbende bedømmelse kendetegnet ved, at den studerende i løbet af kurset deltager i flere læringsaktiviteter, som vurderes og pointgives. Aktiviteterne, som bedømmes, skal som beskrevet i pointe 1 afspejle læringsmålene og kan variere i indhold, antal, vægtning og metoder. Den enkelte bedømmelsesaktivitet kan eksempelvis fokusere på praktiske færdigheder, gruppeprojekter, tests, mundtlige oplæg eller skriftlige opgaver med mulighed for genaflevering (se Figur 1).

Det er desuden vigtigt, at underviseren overvejer, hvordan løbende bedømmelse og feedback indarbejdes $i$ kurset, og hermed sikrer sammenhæng mellem læringsmål, aktiviteter og bedømmelse (constructive alignment). McDowell et al. (2011) viste, at de studerende involverer sig i dybdelæring, når udprøvningsmiljøet i veldesignede kurser har følgende karakteristik:

- Er rig på formel feedback (fx underviserkommentarer; self-assessment)

- Er rig på uformel feedback gennem dialog og interaktion med medstuderende

- Giver mulighed for at anvende og opøve viden og færdigheder

- Indeholder autentiske og relevante bedømmelsesaktiviteter

- Understøtter studerende i at udvikle autonomi og selvstændighed

- Har en passende balance mellem formative og summative bedømmelser 


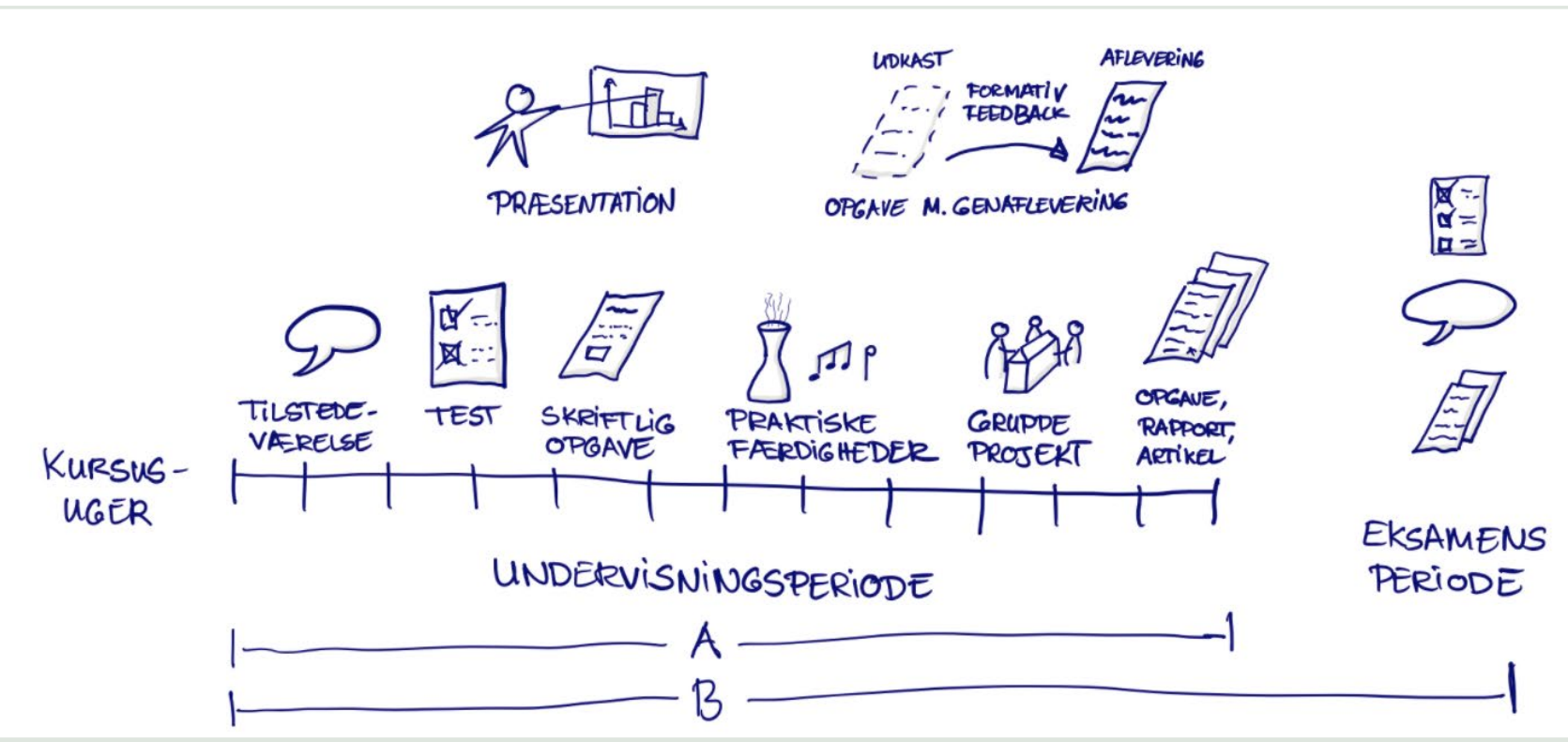

Figur 1: To eksamensformer for løbende bedømmelse. A. Løbende bedømmelse uden afs/uttende eksamen og B. Løbende bedømmelse med afs/uttende eksamen.

A: I løbende bedømmelse uden afs/uttende eksamen optjener den studerende point ved hver udprøvning, og det samlede antal point opsummeres ved afslutningen af semestret og omregnes på dette tidspunkt til en samlet karakter. Karaktererne baseres derfor kun på bedømmelse i løbet af kurset og indeholder altså ikke en afsluttende eksamen. Bemærk at model A ikke praktiseres bredt på alle uddannelser, idet eksamensbekendtgørelsen fortolkes forskelligt. Spørg på din egen uddannelse, om model A er en mulighed for dig - hvis ikke kan du overveje at bruge deltagelseskrav som eksamensform, således at deltagelsen handler om deltagelse i den løbende bedømmelse.

B: I løbende bedømmelse med afsluttende eksamen kombineres den løbende bedømmelse i løbet af semestret med en afsluttende eksamen, og der afgives en samlet karakter. Set ud fra et læringsmæssigt perspektiv giver den afsluttende eksamen mulighed for at udprøve læringsmål, hvor den studerende fx skal sammenfatte og diskutere viden og færdigheder på tværs af hele kurset og ikke som isolerede delmængder. Intentionen er som beskrevet af Gibbs (2006): "Examinations may induce integration of previously unconnected knowledge, during revision or memorisation of unprocessed information". Til den afsluttende eksamen er det desuden lettere at kvalitetssikre (fx med ekstern censur) og at eksaminere individuelle studerende i et fælles gruppeprojekt.

I model B kan løbende bedømmelsesaktiviteter desuden fungere som niveauafklaring forud for den afsluttende eksamen. Det kunne eksempelvis være tre multiple choice-tests, som hver vægter $5 \%$, og som de studerende gennemfører inden den afsluttende multiple choice-eksamen. Det kunne også være små mundtlige oplæg, som vægter $10 \%$, og som fungerer som niveauafklaring inden en mundtlig afsluttende eksamen.

\section{Pointe 3: Lad være med at stresse de studerende}

En væsentlig intention med løbende bedømmelse er at fjerne de hårde tidsbegrænsninger, som kendetegner en traditionel eksamen. Studerende, som ikke er bundet stramt tidsmæssigt, har bedre mulighed for at producere arbejde af høj akademisk kvalitet (Bassey, 1971; Richardson, 2015). Blandt andet derfor er det vigtigt 
ikke blot at kopiere de samme mekanismer som i traditionelle eksamener i en løbende bedømmelseskontekst ved at stresse de studerende med fx mange deadlines. I stedet for at have eksempelvis en ugentlig aflevering, som skal godkendes, og som er udbredt i mange tekniske og naturvidenskabelige discipliner, kan den måske erstattes af en aflevering med feedback hver anden eller tredje uge, som så tæller med i den samlede bedømmelse. Tanken her er: Hellere få gennemarbejdede opgaver med høj kvalitet end mange opgaver med lavere kvalitet. Desuden er snyd med eksamener på videregående uddannelser mere udbredt, hvor studerende oplever at være presset på tid, og hvor eksamener opleves som havende "høj risiko" (Dawson, 2021).

En anden intention med løbende bedømmelse er at give studerende mulighed for at opøve viden og færdigheder gennem hele kurset. Derfor kan der gives flere iterationer, så den studerende ikke bedømmes på det første forsøg, men har mulighed for at forbedre sig gennem feedback, og derfor først bedømmes på andet eller et senere forsøg (se Figur 4). Et eksempel er multiple choice-tests med instantan feedback og mulighed for genaflevering eller afleveringer med feedback loop (Bjælde \& Lindberg, 2018). Her kan det dog være vigtigt, at underviseren overvejer, om den studerende kan komme til at anvende unødig megen tid på at forbedre et resultat i stedet for at fokusere på læring, selvom det nok ofte kan være svært at adskille resultatforbedring og læring i praksis.

Antallet og vægtningen af bedømmelser, mulighed for feedback og forbedring samt den generelle studiebelastning bør afstemmes inden for kurset og inden for semestrets kurser for at sikre, at de studerende har mulighed for dybdelæring. Løbende bedømmelse bør planlægges som en del af læringsprocessen og ikke som en parallel formynderisk aktivitet (McDowell et al., 2011; Winstone og Carless, 2020). Det vigtigste råd til underviseren i den forbindelse er at begrunde, hvorfor aktiviteterne er relevante for læringsprocessen og for at beherske viden og færdigheder i kurset. Desuden er muligheden for iterationer og førnævnte opmærksomhed på antallet af $\mathrm{fx}$ afleveringer vigtig. Et eksempel kunne være at have en aflevering fordelt over tre uger (aflevering i uge 1, feedback i uge 2, genaflevering i uge 3) i stedet for tre forskellige afleveringer i hver uge.

I de engelsktalende universitetssystemer med mange løbende udprøvninger kan antallet virke stressende og demotiverende for de studerende (Sambell et al., 2013), men det samme kan gøre sig gældende, hvis de studerende kun har få "højrisiko"-eksamener, og mange studerende lærer derfor aldrig at håndtere eksamenspresset (Raaheim, 2016). Eksamensangst ses specielt, hvis eksamen af de studerende anses for at være "held eller uheld", som kan være tilfældet ved mundtlige eksamener, hvor de studerende trækker et eksamensspørgsmål inden for en begrænset del af pensum (Andersen \& Tofteskov, 2016). Derfor kan man som underviser vælge, at fx kun de fem bedste ud af syv afleveringer tæller med i den løbende bedømmelse.

\section{Pointe 4: Gør bedømmelse mere autentisk}

Løbende bedømmelse giver i højere grad end traditionelle eksamensformer mulighed for, at de studerende bedømmes på autentiske læringsaktiviteter. Traditionelle mundtlige og skriftlige eksamener er ofte individuelle, tidsbegrænsede præstationer med begrænsede hjælpemidler til rådighed. Disse eksamener afspejler ikke det generelle arbejdsmarked, hvor samarbejde, informationssøgning og digitale teknologier er en naturlig del af arbejdsmetoderne. Sambell, McDowell og Montgomery (2013) foreslår tre måder at udarbejde autentiske udprøvninger på: 1) Ved at styrke den studerendes opfattelse af relevans og betydning af udprøvningen. Den studerende udarbejder eksempelvis ikke en beskrivelse af et kompliceret emne til underviseren, men målretter denne til en specifik målgruppe. De studerendes engagement og motivation kan også styrkes gennem udprøvninger, hvor de samarbejder om komplekse forskningslignende spørgsmål med mange ligeværdige løsningsmuligheder. 2) Ved at relatere udprøvninger til virkelighedens verden. Denne form for udprøvning ses 
ofte for professionsrettede uddannelser, men kan også for ikke-professionsrettede uddannelser simuleres ved at efterligne arbejdsformer, som anvendes på arbejdsmarkedet. Et simpelt eksempel er blot at tillade adgang til internettet. 3) Ved at give den studerende mulighed for personligt engagement gennem eksempelvis emnevalgfrihed eller fokus på personlig refleksion.

Bemærk, at de tre forslag til autentiske udprøvninger godt kan lade sig gøre i en afsluttende eksamen - men at det vil være svært i fx en fire-timers skriftlig eksamen. Derfor er det i lige så høj grad et argument for alternative bedømmelsesformer, hvad enten de er løbende eller afsluttende.

\section{Pointe 5: Giv mere anvendelsesorienteret feedback}

Løbende bedømmelse giver den studerende en indikation af, i hvor høj grad han/hun opfylder læringsmålene gennem fx de point, som den studerende opnår i forbindelse med den enkelte udprøvning fx 25 point ud af 30 mulige. Denne summative feedback bør - hvor det er muligt - suppleres med læringsorienteret formativ feedback. Den formative feedback skal muliggøre, at den studerende kan se sine fejl (feedback), får inspiration til, hvordan han/hun forbedrer sig (feed forward) samt ved, hvordan en god præstation ser ud (feed up) (Hattie \& Timperley, 2007).

Bedømmelses- og feedbackprocessen bør designes, så den studerende ofte har mulighed for direkte at anvende den formative feedback gennem fx genaflevering af opgaver (Boud \& Molloy, 2013). Ved genaflevering skal den studerende ikke blot læse feedbacken, men skal kunne forstå, hvad feedbackgiveren har til hensigt og efterfølgende tage stilling til, hvordan opgaven forbedres, så feedbackprocessen tager form som et meningsskabende spor (Esterhazy \& Damsa, 2017). At anvende den formative feedback beskrives i feedbacklitteraturen som at afslutte et feedback loop (Carless and Boud, 2018; Carless, 2019). Fokus er på, hvordan den studerende forstår, anvender og deltager aktivt i feedbackprocessen (Carless \& Winstone, 2020). Denne mulighed for at agere på feedback vurderes endvidere mere positivt af de studerende sammenlignet med blot at få mere feedback (Gibbs, 2006).

Når der gives anvendelsesorienteret feedback, er det desuden vigtigt at have læringsmål for øje. Donovan (2014) viste, at det var mere sandsynligt, at studerende reagerede på kommentarer, som vedrørte simple læringsmål, som $\mathrm{fx}$ antallet af cifre, layout af en figur eller grammatik, sammenlignet med kommentarer, som vedrørte mere komplekse læringsmål som fx argumentation eller metode. Det er særligt et problem, da især den sidste type kommentarer har til hensigt at udvikle studerendes forståelse eller færdigheder til et højere niveau (Donovan, 2014). Til gengæld kan den type udviklende kommentarer måske vise sig lærerige i det lange løb (Nicol and Macfarland-Dick, 2011; McLean et al., 2015). Af den grund er det vores anbefaling at være tydelig med bedømmelseskriterier; at inkludere såvel simple kriterier som mere komplekse; og at gøre studerende opmærksomme på, hvis feedback involverer forståelse på et højere niveau. At samle kriterierne i en rubric kan ligeledes være en god ide, da en rubric både kommunikerer kriterier og standarder for forskellig grad af opfyldelse (se Figur 2). På den måde fungerer en rubric også som forventningsafstemning. Når studerende efterfølgende får feedback ved hjælp af en rubric, kan de således både se, hvilke kriterier som er opfyldt, og hvilke som ikke er det. Og får de mulighed for at genaflevere, kan de fokusere deres indsats på det eller de kriterier, som ikke er opfyldt. 


\begin{tabular}{|c|c|c|c|c|}
\hline Resultater & $\begin{array}{l}\text { Centrale } \\
\text { fund/resultater } \\
\text { fremgår tydeligt og er } \\
\text { præsenteret korrekt, } \\
\text { læsbart og uden } \\
\text { mangler eller fejl. }\end{array}$ & $\begin{array}{l}\text { Centrale } \\
\text { fund/resultater } \\
\text { fremgår tydeligt, } \\
\text { og er korrekte og } \\
\text { læsbare. Dog er } \\
\text { der enkelte } \\
\text { mangler eller fejl. }\end{array}$ & $\begin{array}{l}\text { Nogle centrale } \\
\text { fund/resultater } \\
\text { fremgår, men } \\
\text { nogle mangler. } \\
\text { Nogle fund er ikke } \\
\text { præsenteret } \\
\text { korrekt, og der er } \\
\text { flere fejl og } \\
\text { mangler. }\end{array}$ & $\begin{array}{l}\text { Fund/resultater er } \\
\text { ikke præsenteret } \\
\text { klart og læsbart. } \\
\text { Data er behæftet } \\
\text { med fejl og } \\
\text { mangler. }\end{array}$ \\
\hline Diskussion & $\begin{array}{l}\text { Konklusioner holder } \\
\text { og hænger logisk } \\
\text { sammen med data. } \\
\text { Konklusioner } \\
\text { forholder sig til } \\
\text { problemformuleringen } \\
\text { (PF) og } \\
\text { introduktionen. } \\
\text { Implikationer og } \\
\text { potentielle problemer } \\
\text { diskuteres grundigt. }\end{array}$ & $\begin{array}{l}\text { Konklusioner } \\
\text { holder og hænger } \\
\text { logisk sammen } \\
\text { med data. } \\
\text { Konklusioner } \\
\text { forholder sig til PF } \\
\text { og introduktionen. } \\
\text { Implikationer og } \\
\text { potentielle } \\
\text { problemer } \\
\text { diskuteres, men } \\
\text { nogle dele kunne } \\
\text { have været mere } \\
\text { grundige. }\end{array}$ & $\begin{array}{l}\text { Konklusioner } \\
\text { holder delvis og } \\
\text { hænger sammen } \\
\text { med data. } \\
\text { Konklusioner } \\
\text { forholder sig til } \\
\text { dels til PF og til } \\
\text { introduktionen. } \\
\text { Implikationer og } \\
\text { potentielle } \\
\text { problemer } \\
\text { behandles, men } \\
\text { overfladisk, og } \\
\text { nogle overses helt. }\end{array}$ & $\begin{array}{l}\text { Konklusioner } \\
\text { holder ikke og } \\
\text { hænger ikke } \\
\text { sammen med data } \\
\text { og forholder sig } \\
\text { ikke til PF og } \\
\text { introduktionen. } \\
\text { Implikationer og } \\
\text { potentielle } \\
\text { problemer berøres } \\
\text { ikke eller kun } \\
\text { meget overfladisk. }\end{array}$ \\
\hline
\end{tabular}

Figur 2: Udsnit af en rubric omhandlende skriftligt arbejde i biologi med kriterierne Introduktion, Metode, Resultater (vist), Analyse og Diskussion (vist) (Jensen \& Jørgensen, ikke publiceret).

Winstone og Carless (2020) lægger vægt på, at bedømmelse og feedback er tæt forbundne og derfor bør planlægges samtidigt. Dette eksemplificeres ved 4 måder, hvorpå løbende bedømmelsesaktiviteter kan designes for at sikre, at de studerende har mulighed for at anvende den feedback, de får. 


\section{I: OPGAVE SERIER II: TO DELT OPGAVE

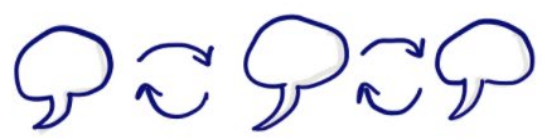

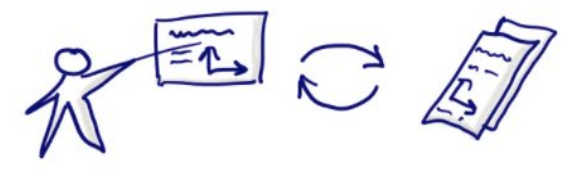

\section{III: UDKAST OG GENAFLEVERING IV: FORBEREDENDE OPGAVE}
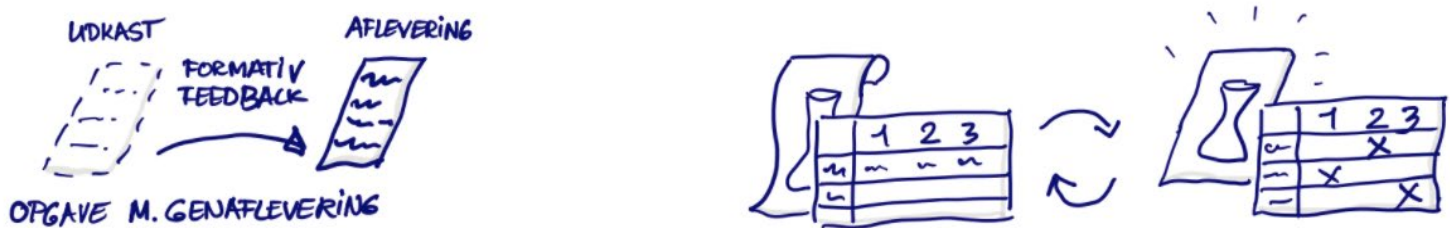

Figur 3. Fire feedbackdesign, som øger den studerendes anvendelse af feedback (gentegninger af figur fra Winstone og Carless, 2020). I: Feedback fra en opgave kan anvendes på efterfølgende opgaver. II: Feedback på den første opgave kan direkte anvendes på den anden opgave. III: Detaljeret feedback på udkast anvendes direkte til forbedring af den endelige aflevering. IV: Studerende arbejder med eller udvikler bedømmelseskriterier, inden de afleverer en opgave, som bedømmes med disse kriterier.

\section{V: GENTAGENDE AFLEVERINGER}

\section{VI: DOBBELT FEEDBACK LOOP}
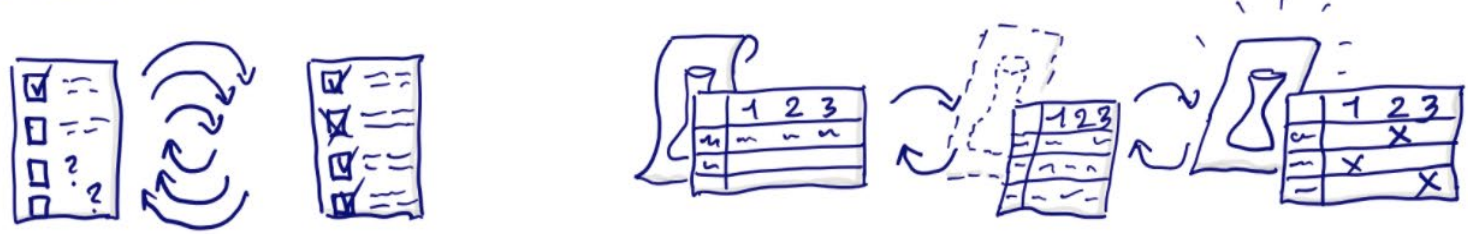

Figur 4. To feedbackdesign, som øger den studerendes anvendelse af feedback (gentegninger af figur fra Bjælde \& Lindberg, 2018). V: Studerende har flere antal prøveforsøg med summativ og formativ feedback. VI: Studerende arbejder med eller udvikler bedømmelseskriterier, inden de afleverer et udkast. Feedback på udkast anvendes til den endelige aflevering.

At sætte fokus på anvendelsesorienteret feedback og feedback loops kan ses som et naturligt næste skridt efter indførelsen af løbende bedømmelse, men også som en nytænkning i det danske videregående uddannelsessystem, som måske kræver en kulturændring fra den praksis, mange kender i dag (selvom der findes mange gode danske eksempler på anvendelsesorienteret feedback). En sådan kulturforskel kan ses $i$ sammenligningen mellem britiske og australske universitetsunderviseres holdning til feedback, udført af Winstone \& Boud (2018). Deres forskning viser bl.a., at australske universitetsundervisere lægger større vægt på, at deres feedback bliver anvendt af studerende end deres britiske kolleger. Forskellen kan tilskrives, at britiske universiteter lægger mest vægt på accountability (national student survey, ekstern censur, 
sammenligninger mellem universiteter), mens australske universiteter er mere fokuseret på læring (Winstone \& Boud, 2018). Samtidig viser Winstone \& Boud (2018), at den primære kilde til inspiration til egen praksis i både Storbritannien og Australien er undervisernes egne erfaringer som studerende. Hvis der skal en kulturændring til i Danmark, er der på nuværende tidspunkt både ministeriel opbakning samt inspiration og forskningsmæssig evidens, som viser, at læring kan styrkes med løbende bedømmelse og anvendelsesorienteret feedback.

\section{Pointe 6: Brug de studerende som ressource}

At give feedback på kvaliteten af et stykke arbejde til andre er noget af det mest lærerige, man kan beskæftige sig med (Schneider \& Preckel, 2017). Derfor har mange undervisere en meget veludviklet sans for at spotte både kvalitet og mangel på kvalitet i studerendes arbejde, fordi de har rettet et utal af opgaver. Studerende kan naturligvis også opøve den kompetence i læringsaktiviteter med peer-feedback/peer-assessment, som vinder frem mange steder inden for videregående uddannelser. Det skyldes sandsynligvis også, at feedback er tidskrævende, sådan at studerende ved at udføre et mindre arbejde - ved $f x$ at give feedback til to medstuderende - kan aflaste underviseren for et stort stykke arbejde.

I løbende bedømmelsesaktiviteter kan peer-feedback på den måde udgøre både en aflastning for underviseren og være første skridt $i$ et feedback loop, hvorved studerende kan genaflevere efter peer-feedback. Peerfeedback kan både finde sted synkront i et klasserum eller asynkront og digitalt; det vigtige er at skabe rum for anvendelse af feedback samt at skabe interaktion og samarbejde mellem studerende (Gibbs, 2006).

For at hjælpe studerende med at give værdifuld feedback til hinanden, kan der med fordel benyttes bedømmelseskriterier. Det hjælper studerende til at få øje på kvaliteterne i en opgave (Winstone \& Carless, 2020) og dermed også til at vurdere kvaliteten af deres egen opgave, som de naturligt vil spejle i opgaven, de selv giver feedback på. Det er dog væsentligt, at peer-feedback ikke skal være en erstatning for samarbejde mellem studerende, da den hurtigste og mest udbredte feedback er den, studerende giver hinanden, mens de læser tekster, regner opgaver og generelt studerer sammen (Gibbs, 2006). Peer-feedback kan således blive en måde at supplere, systematisere og i nogle tilfælde anonymisere feedback mellem studerende på samt at give studerende en øget bevidsthed om egne faglige evner ( $f x$ Simonsmeier, 2020, $i$ en kontekst af akademisk skrivning).

For undervisere, som bruger peer-feedback, er det formentlig ikke ukendt at møde modstand blandt en del studerende, som ikke oplever at få feedback af høj nok kvalitet. Det kan skyldes, at studerende ikke ser hinanden som eksperter (McLean, 2015), som har de rigtige svar eller den rigtige metode til at løse en given opgave. Derfor kan det anbefales at undgå såkaldt "feedback as telling" (McLean, 2015), hvor studerende blot fortæller hinanden, hvad de mener er rigtigt ( $\mathrm{fx}$ ved flueben) eller forkert ( $\mathrm{fx}$ ved et minus eller kort kommentar) - en feedbacktype, som er meget udbredt, også for mange undervisere. I stedet kan det anbefales at benytte kriterier (McLean, 2015), som i stedet handler om at guide ( $f x$ ved at pege en medstuderende i den rigtige retning), at udvikle forståelse ( $f x$ ved at forklare en faglig sammenhæng) eller ved at åbne nye perspektiver ( $f x$ ved at tilbyde en alternativ holdning eller forklaring).

\section{Pointe 7: Vær opmærksom på, hvad du må og ikke må juridisk}

Den lille tilføjelse "mv." (i Eksamensbekendtgørelsen, 2020), som muliggør løbende bedømmelse, synes umiddelbart at give ret vide rammer for forskellige måder at praktisere løbende bedømmelse på. Det har derfor 
været op til hver institution at fastlægge rammer for brugen af løbende bedømmelse lokalt med store forskelle som resultat. Særligt udfordrende er kravet om, at alle studerende skal have tre forsøg til hver eksamen eller deleksamen. Løbende bedømmelse er lidt i en gråzone, for er en opgave, som tæller $10 \%$ af eksamenskarakteren, en deleksamen? Hvis det vurderes som en deleksamen, er der risiko for en stor administrativ byrde, som er en væsentlig grund til, at tommelfingeren er blevet vendt nedad for løbende bedømmelse på nogle videregående uddannelser. Andre steder har løsningen været at bruge betegnelsen "helhedsvurdering" i kursusbeskrivelserne, således at løbende bedømmelse bliver en art portfolio-eksamen, hvor kvalitetsvurderingen sker løbende og ikke til slut. De $10 \%$, som den førnævnte opgave tæller, bliver derfor vejledende, og den endelige karakterfastsættelse finder først sted i afslutningen af kurset under votering mellem eksaminator og en eventuel ekstern censor. Fra en ikke-systematisk dialog med forskellige undervisere og fra vores egen erfaring betyder det i praksis, at hvis en studerende efter løbende bedømmelse og afsluttende eksamen samlet set er på vippen mellem to karakterer, vil censor og eksaminator genbesøge de løbende bedømmelsesaktiviteter for at vurdere den rigtige samlede karakter. Den klare anbefaling er derfor at være tydelig med, hvor mange procent hver løbende bedømmelsesaktivitet tæller, men også samtidig angive det som cirkatal eller på anden vis tydeligt markere, at aktiviteterne (også) bedømmes samlet til slut i en helhedsvurdering.

En yderligere juridisk udfordring er kravet om ekstern censur på en vis procentdel af hver enkelt studerendes videregående uddannelse. Med løbende bedømmelse vil mængden af bedømte opgaver eller andre aktiviteter således øges, og det kan blive et umuligt ønske at få en ekstern censor til at vurdere alle disse opgaver. Mulige alternative løsninger kan være at involvere censor i udformningen af opgaver, således at fx en multiple choicetest bliver kvalitetssikret, inden den benyttes som løbende bedømmelse, eller at der er ekstern censur på de løbende bedømmelsesaktiviteter, som vægter mest. Et andet vigtigt opmærksomhedspunkt er at vælge løbende bedømmelsesaktiviteter, som munder ud i et produkt, som bedømmes - $\mathrm{fx}$ en skriftlig besvarelse, et projekt eller lignende. På den måde kan der ved en eventuel klagesag altid ske en genvurdering af produkterne, så den studerende kan få en retfærdig behandling. Desuden kan den eksterne censor have adgang til produkterne, som typisk uploades i et Learning Management System eller eksamenssystem. Et underliggende pointsystem og tydelige bedømmelseskriterier vil ligeledes være at foretrække, da begge dele kan tages op i tvivlstilfælde under votering mellem censor og eksaminator.

Endelig vil vi opfordre til at adskille løbende bedømmelse fra forudsætningskrav. Hvis en aktivitet tæller med i karakteren som løbende bedømmelse, skal den ikke også være et forudsætningskrav. Den sammenblanding kan skabe unødigt administrativt bøvl, for risikerer man så at indstille en studerende til eksamen for blot at dumpe den studerende med det samme, hvis kvaliteten af besvarelsen ikke er høj nok. Eksamensbekendtgørelsen er det bindende juridiske dokument, men der er en del elastik i formuleringerne, som nødvendiggør en lokal eller national fortolkning. Desuden giver en opgave, som er et forudsætningskrav for at blive indstillet til eksamen, ikke samme motivation for at levere arbejde af så høj kvalitet som muligt.

\section{Pointe 8: Anvend data til at forbedre din løbende bedømmelse iterativt}

Løbende bedømmelse sker i reglen i et Learning Management System, således at både studerende og underviser kan holde styr på opgaver, forudsætninger og bedømmelseskriterier, og således at både bedømmelse/point og feedback er lette at dele med studerende. Derfor skabes der i løbende bedømmelse betragtelige mængder af data, som kan informere om både kvaliteten af studerendes præstationer og om progressionen, sværheds- 
graden af opgaver samt om kvaliteten af bedømmelsesaktiviteterne. Alle disse informationer er potentielt værdifulde kilder til evaluering og kvalitetssikring.

Særligt relevant er løbende bedømmelsesaktiviteter med genaflevering, som kan give værdifulde informationer om studerendes anvendelse af feedback (Bjælde \& Lindberg, 2018; Boud \& Molloy, 2013). Som underviser giver det mulighed for at identificere studerende, som har brug for hjælp samt at følge studerendes progression og læring (Bjælde \& Lindberg, 2018; Bjælde et al., 2018). Eksempler på den type værdifulde data er studerendes pointscorer i multiple choice-quizzer, studerendes feedback og pointscorer i afleveringer (med eller uden genaflevering), bedømmelser i rubrics med prædefinerede kriterier eller studerendes peer-feedback til hinanden - alle eksempler på data, som kan analyseres, og som der kan handles på - assessment analytics (Ellis, 2013).

\section{Afsluttende bemærkninger}

Løbende bedømmelse er en eksamensform med stort potentiale til at styrke studerendes læring på de videregående uddannelser. Men løbende bedømmelse i sig selv er ingen garanti for bedre læring og kræver veldesignede bedømmelsesaktiviteter, som er tilpasset og indarbejdet med omtanke i undervisningen. De otte råd herover er en (start)hjælp til at indføre løbende bedømmelse i din undervisning eller i din rådgivningspraksis som undervisningsudvikler. Der findes desuden mange andre steder, du kan supplere din viden om løbende bedømmelse, eksempelvis http://www.assessmentdecisions.org (Assessment Design Decisions), Eksamensrevolusjonen (Raaheim, 2016) eller https://stll.au.dk/en/resources/assessment-methods/ (Assessment Methods).

\section{Tak til:}

Vi vil gerne takke Peter Josef Wick for fremragende feedback på artiklen, som er blevet anvendt i et feedback loop. Desuden er vi taknemmelige for, at Tove Hedegaard Jørgensen gav os lov til at vise et udsnit af en rubric fra hendes biologiundervisning.

\section{Referencer}

Andersen, H. L. \& Tofteskov, J. (2016). Eksamen og eksamensformer: betydning og bedømmelse, 2. udgave. Frederiksberg: Samfundslitteratur.

Assessment Design Decisions. http://www.assessmentdecisions.org. Besøgt 9/7 2021.

Assessment Methods. https://stll.au.dk/en/resources/assessment-methods/. Besøgt 9/7 2021.

Bassey, M. (1971). The Assessment of Students by Formal Assignments. Wellington: New Zealand University Students Association.

Biggs, J. \& Tang, C. (2007). Teaching for quality learning at university, 3. udgave. Maidenhead, England: Society for Research into Higher Education \& Open University Press.

Biggs, J. \& Tang, C. (2011). Teaching for quality learning at university. McGraw-hill education (UK).

Bjælde, O. E., Jørgensen, T. H. \& Lindberg, A. B. (2017). Continuous assessment in higher education in Denmark: Early experiences from two science courses. Dansk Universitetspædagogisk Tidsskrift, 12(23), 1-19. 
Bjælde, O. E. \& Lindberg, A.B. (2018). Using continuous assessment with feedback loops to generate useful data for learning analytics. In M. Campbell, J. Willems, C. Adachi, D. Blake, I. Doherty, S. Krishnan, S. Macfarlane, L. Ngo, M. O'Donnell, S. Palmer, L. Riddell, I. Story, H. Suri \& J. Tai (Eds.), Open Oceans: Learning without borders. Proceedings ASCILITE 2018. Geelong (53-62).

Bjælde, O. E, Lauridsen, K. M. \& Lindberg, A.B. (2018). White paper on "Current trends in assessment in Europe". The Coimbra Group Education Innovation Working Group. https://www.coimbra-group.eu/whitepaper-on-current-trends-in-assessment-in-europe/

Bjælde, O. E. \& Najbjerg, R. B. (2017). Innovativ formidling af førsteårsstuderende som et design-based research-forløb. Læring og medier (LOM), Vol. 9, No. 16.

Boud, D. \& Molloy, E. (2013a). Rethinking models of feedback for learning: the challenge of design, Assessment \& Evaluation in Higher Education, 38:6, 698-712.

Carless, D. (2015). Excellence in University Assessment. London: Routledge.

Eksamensbekendtgørelsen (2020). https://www.retsinformation.dk/eli/lta/2020/22. Besøgt 9/7 2021.

Carless, D. \& Boud, D. (2018). The development of student feedback literacy: enabling uptake of feedback, Assessment \& Evaluation in Higher Education, 43:8, 1315-1325.

Carless, D. (2019). Feedback loops and the longer-term: towards feedback spirals, Assessment \& Evaluation in Higher Education, 44:5, 705-714.

Dawson, P. (2021). Defending assessment security in a digital world: preventing e-cheating and supporting academic integrity in higher education, Taylor \& Francis: Abingdon.

de la Harpe, B., Peterson, J. F., Frankham, N., Zehner, R., Neale, D., Musgrave E. and McDermott R. (2009). Assessment Focus in Studio: What is Most Prominent in Architecture, Art and Design? Journal of Art \& Design Education, Vol. 28, No. 1, 37-51.

Donovan, P. (2014). Closing the feedback loop: physics undergraduates' use of feedback comments on laboratory coursework, Assessment \& Evaluation in Higher Education, 39:8, 1017-1029.

Ellis, C., (2013). Broadening the Scope and Increasing the Usefulness of Learning Analytics: The Case for Assessment Analytics. British Journal of Educational Technology, 44(4), 662-664.

Gibbs, G. \& Lucas, L. (1997). Coursework assessment, class size and student performance:1984-94. Journal of Further and Higher Education, Vol 21, no 2, 183-192, DOI: 10.1080/0309877970210204.

Gibbs, G. (2006). How assessment frames student learning. In C. Bryan \& K Clegg (Eds.). Innovative Assessment in Higher Education (pp23-36). London: Routledge

Hattie, J. \& Timperley, H. (2007). Review of Educational Research, Vol. 77, No. 1, 81-112.

Hattie, J. (2015). The applicability of Visible Learning to higher education. Scholarship of Teaching and Learning in Psychology, 1(1), 79-91. https://doi.org/10.1037/stl0000021 
Heywood, J. (2000). Assessment in Higher Education. London: Jessica Kingsley.

Hunt, L., Koenders, A. \& Gynnild, V. (2012). Assessing practical laboratory skills in undergraduate molecular biology courses, Assessment \& Evaluation in Higher Education, 37:7, 861-874.

Jensen, T. W. \& Jørgensen, T. H. Rubric: Videnskabelig artikel med IMRAD-struktur (Introduktion, Metode, Resultater, Analyse, Diskussion). Ikke-publiceret.

McDowell, L., Wakelin, D., Montgomery, C. \& King, S. (2011) Does assessment for learning make a difference? The development of a questionnaire to explore the student response, Assessment \& Evaluation in Higher Education, 36:7, 749-765.

McLean, A. J., Bond, C. H. \& Nicholson, H. D., (2015). An anatomy of feedback: a phenomenographic investigation of undergraduate students' conceptions of feedback, Studies in Higher Education, 40:5, 921-932.

Newble, D., Dawson, B., Dauphinee, D., Page, G., Macdonald, M., Swanson, D., Mulholland, H., Thomson, A. \& van der Vleuten, C. (1994). Guidelines for assessing clinical competence, Teaching and Learning in Medicine, $6: 3,213-220$.

Nicol D. J. \& Macfarlane-Dick, D. (2006): Formative assessment and self-regulated learning: a model and seven principles of good feedback practice, Studies in Higher Education, 31:2, 199-218

http://dx.doi.org/10.1080/03075070600572090

Raaheim, A. (2016). Eksamensrevolusjonen. Råd og tips om eksamen og alternative vurderingsformer. Oslo: Gyldendal Norsk Forlag.

Ramsden, P. (2003). Learning to teach in higher education, 2. udgave. London: Routledge/Falmer.

Richardson, J.T.E. (2015). Coursework versus examinations in end-of-module assessment: a literature review, Assessment \& Evaluation in Higher Education, Vol 40, No. 3, 439-455.

Sambell, Kay, Liz McDowell and Catherine Montgomery (2013). Assessment for Learning in Higher Education. London: Routledge.

Schneider, M. \& Preckel, F. (2017). Variables associated with achievement in higher education: A systematic review of meta-analyses. Psychological Bulletin, 143(6), 565-600.

Simonsmeier, B.A., Peiffer, H., Flaig, M. \& Schneider, M. (2020). Peer Feedback Improves Students' Academic Self-Concept in Higher Education. Research in Higher Education,61:706-724.

ten Cate, O., Carraccio, C., Damodaran, A., Gofton, W., Hamstra, S.J., Hart, D.E., Richardson, D., Ross, S., Schultz, K., Warm, E.J, Whelan, A.J. and Schumacher, D.J, (2021) Entrustment Decision Making: Extending Miller's Pyramid. Academic Medicine, Vol. 96, No. 2, 199-204

Trotter, E. (2006). Student perceptions of continuous summative assessment. Assessment \& Evaluation in Higher Education, Volume 31, 2006 - Issue 5. 
Universitetsuddannelser til fremtiden (2018). Udvalg om bedre universitetsuddannelser - Uddannelses- og Forskningsministeriet. https://ufm.dk/publikationer/2018/universitetsuddannelser-til-fremtiden. Besøgt 9/7 2021.

Winstone, N. \& Boud, D. (2019). Exploring cultures of feedback practice: the adoption of learning-focused feedback practices in the UK and Australia, Higher Education Research \& Development, 38:2, 411-425.

Winstone, N. \& Carless, D. (2020). Designing effective feedback processes in higher education. A learningfocused approach. Routledge: Abingdon.

\section{Betingelser for brug af denne artikel}

Denne artikel er omfattet af ophavsretsloven, og der må citeres fra den.

Følgende betingelser skal dog være opfyldt:

- Citatet skal være i overensstemmelse med "god skik"

- Der må kun citeres „i det omfang, som betinges af formålet"

- Ophavsmanden til teksten skal krediteres, og kilden skal angives ift. ovenstående bibliografiske oplysninger

(C) Copyright

DUT og artiklens forfatter
Udgivet af Dansk Universitetspædagogisk Netværk 